\title{
Using Salicylic Acid Treatment of Stored Canola Seed to Decrease the Adversely Effects on Oil quality under Long-Term Storage, High Storage Temperature and Seed Moisture Contents
}

\author{
Fathy Saad El-Nakhlawy ${ }^{1} \&$ Adel Daifallah Al-Qurashi ${ }^{1}$ \\ ${ }^{1}$ Arid Land Agriculture Department, Faculty of Meteorology, Environment and Arid Land Agriculture, King \\ Abdulaziz University, Saudi Arabia \\ Corresponding author: Fathy Saad El-Nakhlawy, Arid Land Agriculture Dept., Faculty of Meteorology, \\ Environment and Arid Land Agriculture, King Abdulaziz University, P.O. Box 80208 Jeddah 21589, Saudi \\ Arabia. Tel: 966-5044-53978. E-mail: falnakhlawi@kau.edu.sa
}

Received: October 22, 2013 Accepted: November 7, 2013 Online Published: December 15, 2013

doi:10.5539/jas.v5n12p75 URL: http://dx.doi.org/10.5539/jas.v5n12p75

\begin{abstract}
This study was carried out on canola seeds stored under different temperatures, seed moisture contents, salicylic acid concentrations for 24 months classified into 4 equal periods. The main objectives of this research were to study the effects of the studied 4 factors and their interactions on fatty acid compositions, acidity and free fatty acids (FFA) of the extracted oil, besides test the effect of treating seeds with salicylic acid to reduce the adversely storage conditions on oil compositions and quality. The obtained results showed that around $10 \%, 46 \%$ and $43 \%$ reductions in oleic, linoleic and linolenic acids as a result of stored seeds under 24 months and 30C compared with 6 months and 10C ,with significantly increasing in oil acidity and FFA. Also, under the 24 months of the $16 \%$ moisture stored seeds highly significantly reductions in oil composition and quality, where percentages of saturated fatty acids (palmitic and stearic) increased and unsaturated fatty acids (oleic, linoleic and linolenic acids) decreased by $23.6 \%, 47.3 \%$ and $49.6 \%$, respectively and both acidity and FFA(\%) increased by around $87 \%$ compared with the 7\% moisture seed stored for 6 months. As seed moisture and storage temperature increased significantly reducing in unsaturated fatty acids and increasing in saturated fatty acids and acidity and FFA. Treating canola seeds with 15 or $30 \mathrm{uM}$ salicylic acid caused in significantly increasing in oleic, linoleic and linolenic acids and decreasing palmitic and stearic acids (\%) besides decreasing the acidity and FFA of the extracted oil from the seeds stored under the unfavorable conditions.
\end{abstract}

Keywords: acidity, canola seed, fatty acids, free fatty acids, oil quality, salicylic acid, storage

\section{Introduction}

Storage conditions of seeds especially oilseeds highly affected the quality of these seeds and their composition from fatty acids. Fatty acids are important component in the oil where oil quality related to the kinds of the fatty acids and its number of double bonds, accordingly the stability of oil during seed storage depends on fatty acids of oil. (Martini \& Anon, 2005; Merello et al., 2004).

The period of storage and storage temperature are the most important factors affecting the concentrations of fatty acids in the stored oil seeds (Neg \& Anderson, 2005), and moisture of the stored seeds is the most important factors affecting the quantity and quality of the oil extracted from these seeds (Anderson \& Lingnert, 1998; Chen \& Ahn, 1998).

As increasing the time of the sunflower seeds storage there has been an increase in the percentage of free fatty acids in oil (Ghasemnezhad \& Honermeier, 2007). Unfavorable Storage temperature cause changes in the quality of the oil through an oxidation and a change in the oil fatty acid concentration (Krasucki et al., 2002), especially if stored canola seed moisture (\%) is more than 12.5\% (Tys \& Rybacki, 2001), also these unfavorable storage conditions decrease the number of carbon atoms of the fatty acids resulting free fatty acids (Graham, 2008) and high oil acidity (Miquel \& Browse,1995; Sathya et al., 2009, Cassells et al., 2007; Reuss \& Cassells., 2003).

Salicylic acid affects the donor of electrons and causes inhibition of peroxidase enzyme, and increase $\mathrm{H}_{2} \mathrm{O}_{2}$ accumulation and it works to inhibit the growth of pathogens on seeds (Clarke et al., 2001; Chen et al., 1995). 
Salicylic acid affects the mechanism of plant to protect against harmful diseases and pests and therefore makes the protection of plants and seeds (Borsani et al., 2001; Pieters et al., 1998).

Mode of action of Salicylic Acid may be due to its role in the resistance to pathogens by inducing the production of pathogenesis-related proteins (Van Huijsduijnen et al., 1986). It is involved in the systemic acquired resistance in which a pathogenic attack on one part of the plant induces resistance in other parts. The signal can also move to nearby plants by salicylic acid being converted to the volatile ester, methyl salicylate (Taiz \& Eduardo, 2002).

The main objectives of this research were to study the effects of different storage periods, temperature levels and salicylic acid treatments on the oil compositions from fatty acids and oil acidity and free fatty acids (FFA) of canola seeds with different moisture contents.

\section{Materials and Methods}

This study was conducted in the labs of Arid Land Agriculture Department, Faculty of Meteorology, Environment and Arid Land Agriculture, King Abdulaziz University.

\subsection{Experimental Design and Treatments}

Canola (Brassica napus L.) fresh harvested seed samples (100 g/sample) Pactole cv. were sealed in $200 \mathrm{ml}$ glass flasks were distributed in a split split split plot design with 4 replications where the storage temperatures $(10,20$, and $30^{\circ} \mathrm{C}$ ) were the mail plot treatments , 4 storage periods $(6,12,18$ and 24 months) were the sub-plot treatments, 4 seed moisture contents $(7,10,13$ and 16\%) were the sub sub-plot treatments while 3 salicylic acid concentrations $(0.0,15$ and $30 \mathrm{uM})$ were the sub sub sub-plot treatments. Seeds were stored under the previous treatments in 4 environmental chambers for the experimental time. Moisture content samples were maintained using potassium hydroxide solutions according to Solomon (1951).

After each stored period, seeds were dried to constant weight at $60-70^{\circ} \mathrm{C}$ using a precision vacuum oven and subsequently crushed and milled to obtain the seed flour.

Oil was extracted with $\mathrm{N}$ - Hexane $\left(60^{\circ} \mathrm{C}\right)$ for 6 hours in a Soxhlet extractor according to AOAC (2000) and the canola seed oil composition from the saturated and unsaturated fatty acids were determined by Gas Chromatography according to AOCS (1990). Methyl esters of fatty acids were extracted with hexane, and then 1 ul aliquots of extracts were injected into a Gas Chromatography (Varian 3800). The column used was a supelcowax 10 fused-silica capillary column (30 m x $0.32 \mathrm{~nm}$ i.d.; Supelco, Bellefonte, PA).The carrier gas was helium, and the total gas flow rate was $20 \mathrm{ml} / \mathrm{min}$. The injector, oven, and detector temperatures were 240,190 and $260{ }^{\circ} \mathrm{C}$, respectively. The determined saturated fatty acids were palmitic and stearic acids and the unsaturated fatty acids were oleic, linoleic and linolenic acids. Oil acidity was determined by the acid base titration technique (ASTM, 2003), a standard solution of one mole potassium hydroxide solution was used. Free fatty acids (FFA) contents were determined by the method of Modified FFA as described by AOCS (2004).

\subsection{Statistical Analysis}

Statistical analysis of the obtained data was performed using the analysis of variance and mean separation significance test by BLSD according to El-Nakhlawy 2010) using SAS program (SAS 2001).

\section{Results and Discussion}

According to analysis of variance, the main 4 factors (storage period, temperature, seed moisture and salicylic acid treatments) besides all 2-factor interactions were significant, while the 3 factors and 4 -factors interactions were not significant so, the results and discussion will concentrate on the 2-factor interactions effects.

\subsection{Effect of the Interaction Between Storage Period and Temperature}

The present data in Table(1) showed that saturated fatty acids (palmitic and stearic acids) means were highest in the seed stored under the 24 months with $30^{\circ} \mathrm{C}$ and $20^{\circ} \mathrm{C}$ also under the 18 months storage with $30^{\circ} \mathrm{C}$ without significant differences between these 2 treatments. Palmitic acid (\%) were 8.46, 8.05 and 8.11\% and stearic acid (\%) were $5.65,4.92$ and $5.19 \%$ under the last treatments, respectively, while the treatments of the interaction between 6 or 12 months and 20 and $30^{\circ} \mathrm{C}$ resulted the lowest palmitic and stearic (\%). As for unsaturated fatty acids response to the interaction between storage period and temperature, results of Table (1) illustrated that 6 months storage and $10^{\circ} \mathrm{C}$ or $20^{\circ} \mathrm{C}$ treatments were the highest in oleic acid (60.80\% and $60.33 \%$, respectively), while treatments of 24 months with 10,20 and $30^{\circ} \mathrm{C}$ and the treatment of 18 month storage with $30^{\circ} \mathrm{C}$ were the lowest in oleic acid with around $10 \%$ decreasing. Concerning, linoleic acid contents, only the treatment of 6 month $+10^{\circ} \mathrm{C}$ was the significantly higher than the other treatments. No significant differences were shown between all interaction treatments between 24 months or 18 months and temperatures. Around $46 \%$ reduction in linoleic acid concentration occurred as the effect of 24 storage month $+30^{\circ} \mathrm{C}$ compared with 6 month $+10^{\circ} \mathrm{C}$. Also, Linolenic 
acid significantly decreased as temperature increased more than $20^{\circ} \mathrm{C}$ under 6 months, and under the long term storage (24 months) with $20^{\circ} \mathrm{C}$ by around $43 \%$. Oil acidity and free fatty acids (FFA) significantly increased under the storage periods $6,12,18$ months if temperature increased more than $20^{\circ} \mathrm{C}$, but under 24 months if temperature increased more than $10^{\circ} \mathrm{C}$. Acidity increased from 0.98 under $\left(6\right.$ months $\left.+10^{\circ} \mathrm{C}\right)$ to 1.62 and 1.97 under 24 months and 20 and $30^{\circ} \mathrm{C}$, respectively. Also, FFA increased significantly by around doubling under the Last treatment.

Our results showed that increasing storage temperature especially under the long term storage caused an adversely effects on canola seed stored oil through deceasing the concentrations of unsaturated fatty acids, and increasing acidity and free fatty acids in the stored seed oil, and these results confirmed with the results of Ghasemnezhad \& Homermeier (2007).

Table 1. Means of fatty acids (\%), acidity (mg KOH/g) and free fatty acids (\%) of the oil produced from canola seed stored under the interaction between storage period and storage temperature

\begin{tabular}{|c|c|c|c|c|c|c|c|c|}
\hline \multirow{2}{*}{$\begin{array}{l}\text { Storage Period } \\
\text { (month) }\end{array}$} & \multirow{2}{*}{$\begin{array}{c}\text { Temp. } \\
\left({ }^{\circ} \mathrm{C}\right)\end{array}$} & \multicolumn{5}{|c|}{ Fatty acids (\%) } & \multirow{2}{*}{$\begin{array}{c}\text { Acidity } \\
\text { (mg KOH/g) }\end{array}$} & \multirow{2}{*}{$\begin{array}{c}\text { FFA } \\
(\%)\end{array}$} \\
\hline & & Palmitic & Stearic & Oleic & Linoleic & Linolenic & & \\
\hline \multirow{3}{*}{6} & 10 & 4.50 & 2.81 & 60.80 & 17.85 & 8.32 & 0.98 & 0.49 \\
\hline & 20 & 4.61 & 1.93 & 60.33 & 15.52 & 8.41 & 1.08 & 0.50 \\
\hline & 30 & 5.96 & 3.08 & 56.71 & 14.13 & 7.19 & 1.30 & 0.60 \\
\hline \multirow{3}{*}{12} & 10 & 4.91 & 2.89 & 58.71 & 15.29 & 7.55 & 0.95 & 0.48 \\
\hline & 20 & 5.16 & 3.45 & 57.52 & 14.16 & 6.87 & 1.26 & 0.63 \\
\hline & 30 & 5.92 & 3.92 & 55.10 & 13.30 & 6.25 & 1.39 & 0.70 \\
\hline \multirow{3}{*}{18} & 10 & 6.46 & 3.81 & 53.71 & 11.07 & 6.00 & 1.18 & 0.59 \\
\hline & 20 & 6.75 & 4.26 & 52.17 & 10.21 & 5.67 & 1.48 & 0.74 \\
\hline & 30 & 8.11 & 5.19 & 50.55 & 10.18 & 5.25 & 1.59 & 0.80 \\
\hline \multirow{3}{*}{24} & 10 & 6.91 & 4.32 & 52.32 & 10.04 & 5.22 & 1.62 & 0.81 \\
\hline & 20 & 8.05 & 4.92 & 48.90 & 10.45 & 4.78 & 1.78 & 0.89 \\
\hline & 30 & 8.46 & 5.65 & 48.24 & 9.65 & 4.37 & 1.97 & 0.99 \\
\hline $\operatorname{BLSD}(0.05)$ & & 0.68 & 0.77 & 1.78 & 1.63 & 0.54 & 0.20 & 0.05 \\
\hline
\end{tabular}

\subsection{Effect of the Interaction Between Storage Period and Seed Moisture Content}

As shown in Table 2, significant effects were found for the storage period $\mathrm{x}$ seed moisture content interaction on all studied oil characteristics. Stored canola seeds with the same moisture content significantly different under different storage period in all studied characteristics. Generally, as storage period increased, quality of canola oil adversely affected. Reduction of oleic, linoleic and linolenic acids were $23.6 \%, 47.3 \%$ and $49.6 \%$, respectively under the storage treatment of ( 24 storage period $+16 \%$ seed moisture) compared with (6 month storage $+7 \%$ moisture content). Also acidity and FFA of the extracted oil increased with $87 \%$ more than the storage treatment of (6 month storage $+7 \%$ moisture content).

The adversely effects of high moisture content of stored seeds under the long storage periods (more than 6 months) on the canola oil may be due to the embryo activity resulting from increasing seed moisture content and as storage period increased, these unfavorable storage conditions caused hydrolysis of the triglycerides by enzymes that increasing in activity with the activity of micro-organisms that attack the seeds (Sathya et al., 2009, Cassells et al., 2007 , Reuss \& Pratt, 2001; Reuss \& Cassells, 2003).

Unfavorable storage conditions lead to an oxidation reaction and hydrolysis of the double bonds of the unsaturated fatty acids in oil, which leads to a change in their proportions in oil and increase the free fatty acids and acidity of the oil (Canakcii, 2007). 
Table 2. Means of fatty acids (\%), acidity (mg KOH/g) and free fatty acids (\%) of the oil produced from canola seed stored under the interaction between storage period and seed moisture content

\begin{tabular}{|c|c|c|c|c|c|c|c|c|}
\hline \multirow{2}{*}{$\begin{array}{l}\text { Storage Period } \\
\text { (month) }\end{array}$} & \multirow{2}{*}{$\begin{array}{l}\text { Seed Moisture } \\
\text { Content (\% ) }\end{array}$} & \multicolumn{5}{|c|}{ Fatty acids (\%) } & \multirow{2}{*}{$\begin{array}{c}\text { Acidity } \\
\text { (mg KOH/g) }\end{array}$} & \multirow{2}{*}{$\begin{array}{l}\text { FFA } \\
(\%)\end{array}$} \\
\hline & & Palmitic & Stearic & Oleic & Linoleic & Linolenic & & \\
\hline \multirow{4}{*}{6} & 7 & 4.50 & 2.04 & 61.59 & 16.90 & 8.56 & 0.35 & 0.17 \\
\hline & 10 & 4.68 & 2.26 & 60.51 & 16.37 & 8.31 & 0.91 & 0.45 \\
\hline & 13 & 5.23 & 3.01 & 58.30 & 15.36 & 7.71 & 1.33 & 0.70 \\
\hline & 16 & 5.68 & 3.25 & 56.72 & 14.69 & 7.25 & 1.85 & 0.93 \\
\hline \multirow{4}{*}{12} & 7 & 5.08 & 2.83 & 59.89 & 15.50 & 7.67 & 0.42 & 0.21 \\
\hline & 10 & 5.25 & 2.96 & 57.27 & 15.18 & 7.21 & 0.84 & 0.41 \\
\hline & 13 & 5.40 & 3.68 & 56.22 & 13.81 & 6.67 & 1.41 & 0.70 \\
\hline & 16 & 5.58 & 4.21 & 55.06 & 12.50 & 6.02 & 2.14 & 1.07 \\
\hline \multirow{4}{*}{18} & 7 & 5,74 & 3.72 & 54.32 & 11.95 & 6.08 & 0.59 & 0.30 \\
\hline & 10 & 6.23 & 4.22 & 52.98 & 11.30 & 5.90 & 1.21 & 0.60 \\
\hline & 13 & 8.26 & 4.67 & 51.24 & 10.49 & 5.47 & 1.74 & 0.87 \\
\hline & 16 & 8.20 & 5.08 & 50.03 & 9.44 & 5.11 & 2.13 & 1.07 \\
\hline \multirow{4}{*}{24} & 7 & 6.17 & 4.13 & 52.49 & 11.06 & 5.38 & 0.60 & 0.30 \\
\hline & 10 & 6.91 & 4.73 & 50.95 & 10.44 & 4.89 & 1.49 & 0.74 \\
\hline & 13 & 8.62 & 5.19 & 48.84 & 9.80 & 4.57 & 2.33 & 1.17 \\
\hline & 16 & 9.53 & 5.81 & 47.02 & 8.90 & 4.31 & 2.73 & 1.37 \\
\hline \multicolumn{2}{|c|}{$\operatorname{BLSD}(0.05)$} & 0.82 & 0.27 & 0.58 & 0.42 & 0.26 & 0.16 & 0.04 \\
\hline
\end{tabular}

\subsection{Effect of the Interaction Between Storage Temperature and Seed Moisture Content}

Palmitic acid means (Table 3) showed no significance between 7 and 10\% seed moisture contents under any storage temperatures, but significant differences were showed for palmitic and stearic acids of the oil extracted from the same canola seeds stored under different temperatures, where as temperature increased both acids significantly increased.

The unsaturated fatty acids responded with an opposite trend of saturated fatty acids, where their means decreased as increasing temperature and seed moisture levels. Unsaturated fatty acids (\%) of the canola seeds stored significantly decreased when high moisture seeds subjected to high temperature, where oleic acid (\%) significantly decreased with rate of $3.5 \%$ and $6.7 \%$, linoleic acid decreased by $7.6 \%$ and $23.2 \%$ and linolenic acid decreased with $6.8 \%$ and $16.2 \%$ by increasing temperature into $20^{\circ} \mathrm{C}$ and $30^{\circ} \mathrm{C}$, respectively.

Acidity and FFA (\%) significantly increased as temperature + seed moisture increased. The highest acidity and FFA were 2.41 and $1.20 \%$ under $\left(30^{\circ} \mathrm{C}+16 \%\right.$ seed moisture).

The effects of the temperature and seed moisture interaction on the oil quality may be discussed as the storage of high seed moisture under high temperature encourage the bio-activity of seed embryo, accordingly, embryo respiration rate increased caused a high activity of the oxidation and hydrolysis enzymes so, the fatty acid proportion changed and FFA and acidity of the extracted oil increased causing bad effects on oil quality, as stated by Tys and Rybacki (2001); Chen and Ahn (1998); Neg and Anderson (2005). 
Table 3. Means of fatty acids (\%), acidity (mg KOH/g) and free fatty acids (\%) of the oil produced from canola seed stored under the interaction between storage temperature and seed moisture content

\begin{tabular}{|c|c|c|c|c|c|c|c|c|}
\hline \multirow{2}{*}{$\begin{array}{c}\text { Storage } \\
\text { Temperature } \\
\left({ }^{\circ} \mathrm{C}\right)\end{array}$} & \multirow{2}{*}{$\begin{array}{c}\text { Seed Moisture } \\
\text { Content (\% ) }\end{array}$} & \multicolumn{5}{|c|}{ Fatty acids (\%) } & \multirow{2}{*}{$\begin{array}{c}\text { Acidity } \\
\text { (mgKOH/g) }\end{array}$} & \multirow{2}{*}{$\begin{array}{l}\text { FFA } \\
(\%)\end{array}$} \\
\hline & & Palmitic & Stearic & Oleic & Linoleic & Linolenic & & \\
\hline \multirow{4}{*}{10} & 7 & 4.78 & 2.70 & 59.08 & 14.94 & 7.52 & 0.35 & 0.18 \\
\hline & 10 & 5.16 & 2.97 & 57.23 & 14.17 & 7.06 & 0.96 & 0.48 \\
\hline & 13 & 6.03 & 3.87 & 55.18 & 13.14 & 6.49 & 1.46 & 0.73 \\
\hline & 16 & 6.82 & 4.28 & 54.05 & 11.99 & 6.02 & 1.95 & 0.98 \\
\hline \multirow{4}{*}{20} & 7 & 5.34 & 3.1 & 57.00 & 13.80 & 7.01 & 0.48 & 0.24 \\
\hline & 10 & 5.75 & 3.36 & 55.49 & 13.46 & 6.70 & 1.14 & 0.57 \\
\hline & 13 & 6.47 & 3.83 & 53.97 & 12.48 & 6.20 & 1.71 & 0.86 \\
\hline & 16 & 7.00 & 4.37 & 52.45 & 11.52 & 5.81 & 2.27 & 1.14 \\
\hline \multirow{4}{*}{30} & 7 & 6.00 & 3.73 & 55.12 & 12.83 & 6.30 & 0.64 & 0.32 \\
\hline & 10 & 6.39 & 4.29 & 53.56 & 12.33 & 5.98 & 1.23 & 0.61 \\
\hline & 13 & 8.13 & 4.70 & 51.80 & 11.47 & 5.62 & 1.92 & 0.96 \\
\hline & 16 & 8.02 & 5.18 & 49.68 & 10.53 & 5.20 & 2.41 & 1.20 \\
\hline \multicolumn{2}{|c|}{$\operatorname{BLSD}(0.05)$} & 0.50 & 0.17 & 0.38 & 0.27 & 0.17 & 0.10 & 0.03 \\
\hline
\end{tabular}

\subsection{Effect of the Interaction Between Storage Period and Salicylic Acid Treatment}

Using salicylic acid to treat canola seeds stored especially for 18 and 24 months keep the palmitic acid concentration in the oil without significant differences versus under 6 or 12 months storage periods. Significantly differences were found between palmitic acid and stearic acid contents under 0.0 salicylic (SA) in the 12, 18 and 24 months compared with using 15 or 30 uM SA treatments (Table 4).

Table 4. Means of fatty acids (\%), acidity (mg KOH/g) and free fatty acids (\%) of the oil produced from canola seed stored under the interaction between storage period and salicylic acid treatment

\begin{tabular}{|c|c|c|c|c|c|c|c|c|}
\hline \multirow{2}{*}{$\begin{array}{l}\text { Storage Period } \\
\text { (month) }\end{array}$} & \multirow{2}{*}{$\begin{array}{l}\text { Salicylic acid } \\
\text { (uM) }\end{array}$} & \multicolumn{5}{|c|}{ Fatty acids (\%) } & \multirow{2}{*}{$\begin{array}{c}\text { Acidity } \\
\text { (mgKOH/g) }\end{array}$} & \multirow{2}{*}{$\begin{array}{l}\text { FFA } \\
(\%)\end{array}$} \\
\hline & & Palmitic & Stearic & Oleic & Linoleic & Linolenic & & \\
\hline \multirow{3}{*}{6} & 0.0 & 4.11 & 3.63 & 55.24 & 13.51 & 6.48 & 0.34 & 0.18 \\
\hline & 15 & 4.46 & 2.18 & 61.69 & 17.19 & 8.83 & 0.34 & 0.17 \\
\hline & 30 & 4.49 & 2.18 & 60.91 & 16.79 & 8.63 & 0.37 & 0.19 \\
\hline \multirow{3}{*}{12} & 0.0 & 5.44 & 5.03 & 50.94 & 10.73 & 4.87 & 1.11 & 0.55 \\
\hline & 15 & 4.66 & 2.64 & 60.33 & 16.01 & 7.93 & 0.47 & 0.24 \\
\hline & 30 & 4.89 & 2.59 & 60.16 & 16.01 & 7.88 & 0.59 & 0.30 \\
\hline \multirow{3}{*}{18} & 0.0 & 5.82 & 5.63 & 42.68 & 6.02 & 3.12 & 1.11 & 0.55 \\
\hline & 15 & 4.47 & 3.22 & 57.30 & 13.26 & 6.94 & 0.39 & 0.29 \\
\hline & 30 & 4.44 & 3.42 & 56.45 & 13.11 & 6.86 & 0.43 & 0.21 \\
\hline \multirow{3}{*}{24} & 0.0 & 6.17 & 5.79 & 37.73 & 5.07 & 2.49 & 1.31 & 0.65 \\
\hline & 15 & 4.90 & 3.68 & 56.28 & 12.77 & 6.25 & 0.60 & 0.30 \\
\hline & 30 & 4.81 & 3.83 & 55.46 & 12.31 & 5.62 & 0.71 & 0.36 \\
\hline \multicolumn{2}{|c|}{$\operatorname{BLSD}(0.05)$} & 1.18 & 0.91 & 4.70 & 1.77 & 1.05 & 0.10 & 0.02 \\
\hline
\end{tabular}


As for unsaturated fatty acids, statistical comparisons between the means showed that treating canola seeds with 15 or 30 uM SA under 18 and 24 months storage caused significance increasing in oleic, linoleic and linolenic acids (\%) compared with no SA treatment under the long - term storage. Oleic acid (\%) increased by $34 \%$ and $49 \%$, linoleic acid (\%) increased by $120 \%$ and $152 \%$, also linolenic acid increased by $122 \%$ and $151 \%$ as a result of treating seeds with 15 uM SA under 18 and 24 months storage periods, respectively (Table 4).

Positive effects of treating canola stored seeds by SA on oil acidity and FFA (\%), where significant decreasing in both were found as canola seeds treated with 15 or 30 uM SA.

The positive effects of treating canola seeds with SA on oil quality especially under the unfavorable storage conditions may be due the effect of salicylic acid on the donor of electrons and causes inhibition of lipids hydrolysis and oxidation enzymes (Clarke et al., 2001 , Chen et al., 1995, Zhang et al., 2002 , Radwan et al., 2006; El-Saidy \& El-Hai, 2011).

\subsection{Effect of the Interaction Between Storage Temperature and Salicylic Acid}

Palmitic and stearic acid (\%) significantly decreased by treating canola seeds with 15 or 30 uM SA, especially as temperature of storage increased. Unsaturated fatty acids (\%) positively responded to treat canola seed by SA, especially under high storage temperatures $\left(20^{\circ} \mathrm{C}\right.$ or $\left.30^{\circ} \mathrm{C}\right)$. Under $30^{\circ} \mathrm{C}$, oleic, linoleic and linolenic acids (\%) increased by around 35\%, 99\% and $122 \%$, respectively as a result of seed treated by $15 \mathrm{uM} \mathrm{SA}$.

The positive effect of SA on quality of oil extracted from canola seed stored in unfavorable conditions was reflected also in decreasing oil acidity and FFA (\%) by around $50 \%$ under 20 and $30^{\circ} \mathrm{C}$.

Salicylic acid affects the donor of electrons and causes inhibition of peroxides enzyme, and increase $\mathrm{H}_{2} \mathrm{O}_{2}$ accumulation and it works to inhibit the growth of pathogens on seeds under the high storage temperature (Clarke et al., 2001; Chen et al., 1995; Rawshan et al., 2010).

Table 5. Means of fatty acids (\%), acidity (mg KOH/g) and free fatty acids (\%) of the oil produced from canola seed stored under the interaction between storage temperature and Salicylic acid

\begin{tabular}{ccccccccc}
\hline \multirow{2}{*}{$\begin{array}{c}\text { Storage } \\
\text { Temperature }\left({ }^{\circ} \mathrm{C}\right)\end{array}$} & $\begin{array}{c}\text { Salicylic acid } \\
(\mathrm{uM})\end{array}$ & \multicolumn{5}{c}{ Fatty acids (\%) } & $\begin{array}{c}\text { Acidity } \\
(\mathrm{mgKOH} / \mathrm{g})\end{array}$ & $\begin{array}{c}\text { FFA } \\
(\%)\end{array}$ \\
\cline { 3 - 8 } 10 & 0.0 & 5.01 & 2.96 & 58.83 & 10.29 & 4.94 & 0.98 & 0.49 \\
& 15 & 4.98 & 2.83 & 59.86 & 15.18 & 7.61 & 0.89 & 0.45 \\
& 30 & 4.90 & 2.95 & 59.47 & 15.21 & 7.78 & 0.97 & 0.49 \\
20 & 0.0 & 6.60 & 3.42 & 50.14 & 8.97 & 4.55 & 1.99 & 1.00 \\
& 15 & 4.81 & 2.79 & 58.89 & 14.82 & 7.65 & 1.06 & 0.53 \\
& 30 & 5.02 & 2.97 & 58.15 & 14.66 & 7.10 & 1.16 & 0.58 \\
30 & 0.0 & 7.48 & 5.98 & 42.97 & 7.25 & 3.24 & 2.35 & 1.18 \\
& 15 & 5.25 & 3.12 & 57.87 & 14.41 & 7.21 & 1.12 & 0.56 \\
& 30 & 5.52 & 3.20 & 57.26 & 13.92 & 6.98 & 1.12 & 0.56 \\
BLSD(0.05) & & 0.46 & 0.15 & 0.33 & 0.24 & 0.15 & 0.09 & 0.02 \\
\hline
\end{tabular}

\subsection{Effect of the Interaction Between Seed Moisture Content and Salicylic Acid}

As shown in Table (6), generally as stored seed moisture (\%) increased significantly adverse effects were pronounced in oil constituents and quality where saturated fatty acids (\%) significantly increased and unsaturated fatty acids decreased, besides the significance increasing in oil acidity and FFA (\%).

As the high moisture seeds treated with SA (15 or $30 \mathrm{uM})$, palmitic and stearic acids (\%) significantly decreased up to their levels in the 7\% seed moisture or less. Significantly increasing in the percentages of oleic, linoleic and linolenic acids were shown as seeds were treated with SA.

Acidity and FFA (\%) of canola seed oil significantly decreased as a result of highly moisture seeds were treated with SA. 
These results may be due to the protection effects of SA on the high moisture seeds from the infection by microorganisms, accordingly, the bad effects of the high activity of the hydrolysis and oxidative enzymes decreased so, Low acidity and FFA (\%) were shown in the extracted oil (Radwan et al., 2006, Pieterse et al., 1995, Zhang et al., 2002, Chen et al., 1995), also our results confirmed with the results obtained by Borsani et al. (2001) and Pieters et al. (1996) which stated that salicylic acid affects the mechanism of plant to protect against harmful diseases and pests and therefore makes the protection of plants and seeds.

Table 6. Means of fatty acids (\%), acidity (mg KOH/g) and free fatty acids (\%) of the oil produced from canola seed stored under the interaction between Salicylic acid and seed moisture content

\begin{tabular}{|c|c|c|c|c|c|c|c|c|}
\hline \multirow{2}{*}{$\begin{array}{c}\text { Salicylic } \\
\text { acid } \\
\text { ( uM ) }\end{array}$} & \multirow{2}{*}{$\begin{array}{l}\text { Seed Moisture Content } \\
\text { (\%) }\end{array}$} & \multicolumn{5}{|c|}{ Fatty acids (\%) } & \multirow{2}{*}{$\begin{array}{c}\text { Acidity } \\
\text { (mgKOH/g) }\end{array}$} & \multirow{2}{*}{$\begin{array}{l}\text { FFA } \\
(\%)\end{array}$} \\
\hline & & Palmitic & Stearic & Oleic & Linoleic & Linolenic & & \\
\hline \multirow{5}{*}{0.0} & 7 & 5.78 & 4.25 & 57.00 & 11.52 & 5.66 & 0.61 & 0.30 \\
\hline & 10 & 6.57 & 4.92 & 51.79 & 10.35 & 4.88 & 1.46 & 0.73 \\
\hline & 13 & 10.51 & 6.24 & 46.12 & 8.01 & 3.76 & 2.48 & 1.24 \\
\hline & 16 & 11.29 & 7.27 & 40.59 & 5.45 & 2.66 & 3.47 & 1.73 \\
\hline & 7 & 4.56 & 2.60 & 59.41 & 15.12 & 7.67 & 0.46 & 0.23 \\
\hline \multirow{3}{*}{15} & 10 & 4.77 & 2.79 & 59.05 & 14.96 & 7.53 & 0.86 & 0.43 \\
\hline & 13 & 4.97 & 3.00 & 58.68 & 14.65 & 7.41 & 1.25 & 0.62 \\
\hline & 16 & 5.09 & 3.25 & 58.35 & 14.49 & 7.35 & 1.51 & 0.75 \\
\hline \multirow{4}{*}{30} & 7 & 4.78 & 2.69 & 58.79 & 14.93 & 7.51 & 0.41 & 0.21 \\
\hline & 10 & 4.97 & 2.91 & 58.45 & 14.65 & 7.34 & 1.02 & 0.51 \\
\hline & 13 & 5.17 & 3.16 & 58.06 & 14.43 & 7.14 & 1.39 & 0.69 \\
\hline & 16 & 5.22 & 3.15 & 57.93 & 14.42 & 7.19 & 1.59 & 0.79 \\
\hline & $\operatorname{BLSD}(0.05)$ & 0.87 & 0.22 & 0.47 & 0.34 & 0.21 & 0.13 & 0.03 \\
\hline
\end{tabular}

\section{Conclusion}

The main conclusion of this study is the positive effects of treating canola seeds with 15 or $30 \mathrm{uM}$ salicylic acid to decreasing the adversely effects of the unfavorable storage conditions especially on the oil composition from unsaturated, saturated fatty acids and oil acidity and percentage of free fatty acids.

\section{Acknowledgments}

This project was funded by the Development of Science Research (DSR), King Abdulaziz University, Jeddah under grant no. (182/155/1432). The authors therefore acknowledge with thanks DSR, technological and financial support.

\section{References}

Anderson, K., \& Lingnert, H. (1998). Influence of oxygen and copper concentrations on lipid oxidation on rapeseed oil. Journal of the American Oil Chemist's. Society, 75(8), 1041-1046.

Angelo, S. A. (1996). Lipid oxidation in foods. Crit. Rev. Food Sci. Nutr., 36, 175-224. http://dx.doi.org/10.1080/10408399609527723

AOAC: Association of Official Analytical Chemist. (2000). Official Methods of Analysis (17th ed.). Washington, DC.

AOCS: American Oil Chemists Society. (2004). Official Methods and Recommended Practices of the American Oil Chemists Society (4th ed). Champaign: American Oil Chemists Society.

ASTM. (2003). American Standards for Testing OF Materials, D.189-01, D240-02 , D4052-96, D445-03, D482-74, D555-95, D6751-02, D93-02, D95-990, D97-02. 
Becker, R. W., \& Waller, G. R. (1983). Antioxidative arginine-xylose Maillard reaction products: condition for synthesis. Journal of Food Science, 48, 996-997. http://dx.doi.org/10.1111/j.1365-2621.1983.tb14952.x

Borsani, O., Valpuesta, V., \& Botella, M. A. (2001). Evidence for a role of salicylic acid in the oxidative damage generated by NACL and osmotic stress in Arabidopsis seedling. J. Plant Physiol, 126, 1024-1030. http://dx.doi.org/10.1104/pp.126.3.1024

Canakci, M. (2007). The potential of restaurant waste lipids as biodiesel feedstocks. Bioresource Technology, 98, 791-797. http://dx.doi.org/10.1016/j.biortech.2005.11.022

Cassells, J. A., Reuss, R., Osborne, B. G., \& Wesley, I. J. (2007). Near Inferared Spectroscpic studies of changes in stored grain. J. Near Infrared Spectrosc., 15, 161-167. http://dx.doi.org/10.1255/jnirs.727

Chen, X. C., \& Ahn, D. U. (1998). Antioxidant activities of six natural phenolic against lipid oxidation induced by $\mathrm{Fe}+2$ or ultraviolet light. Journal of the American Oil Chemist's. Society, 75(12), 1717-1721. Retrieved from http://www.scopus.com/record/display.url?eid=2-s2.0-0032307488\&origin=inward\&txGid=80E2CAD27B 26F6AD 3129964AD64DD332.FZg2ODcJC9ArCe8WOZPvA\%3a1

Chen, Z., Malamy, J., Hennig, J., Conrath, U., Sanchez-Casas, P., Ricigliano, J., ... Klessing, D. F. (1995). Induction, modification and transduction of the salicylic acid signal in plant defense response. Proc Natl Acad Sci USa, 92, 4134-4137. Retrieved from http://www.pnas.org/content/92/10/4134.short.

Ckarke, J. D., Aarts, N., Feys, B. J., Dong, X., \& Parker, J. E. (2001). Constitutive disease resistance requires EDS1 in the Arabidopsis mutants cpr1 and cpr6 and is partially EDS1-dependent in cpr5. Plant J., 26, 409-420.

El-Nakhlawy, F. S. (2010). Experimental Design and Analysis in Scientific Research. Sci. Pub. Center, King Abdulaziz University, Saudi Arabia.

El-Saidy, A. E., \& El-Hai, K. M. (2011). Alleviation of Peanut seed deterioration during storage using biotic and abiotic agents. Research J.of Seed Sci., 10, 1-18.

Ghasemnezhad, A., \& Honermeier, B. (2007). Influence of storage conditions on quality and viability of high and low oleic sunflower seeds. Inter. J. of Plant Prod., 3(40), 39-47.

Graham, M. A. (2008). Seed storage oil mobilization. Annu.Rev. Plant Biol., 59, 115-142. http://dx.doi.org/10.1146/annurev.arplant.59.032607.092938

Jayas, D. S., \& White, D. G. (2003). Storage and drying of grain in Canada : Low cost approaches. Food Control, 14, 255-261. http://dx.doi.org/10.1016/S0956-7135(03)00014-8

Krusucki, W., Tys, J., Szafran, K., Rybacki, R., \& Orlicki, L. (2002). Influence of various rape seed drying temperatures on their chemical composition. Oil Seed Crops, No.xxIII.S, 427-438.

Martini, S., \& Anon, M. S. (2005). Storage of sunflower seed variation on the wax content of the oil. European Journal of Lipid Science and Technology, 107, 74-79. http://dx.doi.org/10.1002/ejlt.200401044

Merello, J. R., Motilva, M. J., Tavar, M. J., \& Romero, M. P. (2004). Changes in commercial virgin olive (CV Arbequina) during storage with special emphasis on the phenolic fraction. Journal of Food Chemistry, 85, 357-364. http://dx.doi.org/10.1016/j.foodchem.2003.07.012

Miquel, M., \& Browse, J. (1995). Lipid biosynthesis in developing seeds. In J. Kigel, \& G. Golili (Eds.), Seed Development and Germination. New York: Marcel Dekker.

Neg, S. C., \& Anderson, A. (2005). Lipids oxidation in Quinoa (Chenopodium quinoa) as determined through accelerated aging. Journal of environmental Agriculture and Food Chemistry, 4(4), 1010-1020.

Pieterse, C. M., van Wees, S. C., van Pelt, J. A., Knoester, M., Laan, R., Gerrits, Weisbeek, P. J., \& van Loon, L. C. (1998). A novel Signaling pathway controlling induced systemic resistance in Arabidopsis. Plant Cell, 10, 1571-1580. http://dx.doi.org/10.1105/tpc.10.9.1571.

Radwan, D. M., Fayez, K. A., Mahmoud, S. Y., Hamad, A., \& Lu, G. (2006). Salicylic acid alleviates growth inhibition and oxidative stress caused by zucchini yellow mosaic virus infection in Cucurbita pepo leaves. Physiological and Molecular Plant Pathologyu, 69, 172-181. http://dx.doi.org/10.1016/j.pmpp.2007.04.004

Rawshan, V., Khoi, M. K., \& Javidnia, K. (2010). Effects of salicylic acid on quality and quantity of essential oil components in Salvia macrosiphan. J. Biol.Environ. Sci., 4, 77-82.

Raymer, P. L. (2002). Canola: An emerging oilseed crop. In J. Janick, \& A.Whipkey (Eds.), Trends in New Crops and New Uses (pp. 122-126). Alexandria, VA: ASHS Press. 
Reuss, R., \& Cassells, J. (2003). The effect of storage conditions on the quality of Australian canola (rapeseed), Brassica napus L. In P. F. Credland, D. M. Armitage, C. H. Bell, P. M. Cogan, \& E. Highley (Eds.), Advances in stored product protection (pp. 498-503). Wallingford, Oxon, CAB International. http://dx.doi.org/10.1016/S0022-474X(99)00060-0

Reuss, R., \& Pratt, S. (2001). Accumulation of Carbon monoxide and carbon dioxide in stored canola. Journal of Stored Products Research, 37, 23-34.

SAS. (2001). SAS 9.1 TS level IM3, Windows version 5.1 2600. Cary, USA: SAS Institute.

Sathya, G., Jayas, D. S., \& White, N. D. (2009). Safe Storage Guidelines for Canola as the seeds Slowly Dry. Canadian Biosystems Engineering, 51(3), 29-38.

Shakirova, F. M., Shakhabutdinova, A. R., Bezrukova, M. V., Fathundinova, R. A., \& Fathundinova, D. R. (2003). Changes in hormonal status of wheat seedlings induced by salicylic acid and salinity. Plant Sci., 164, 317-322. http://dx.doi.org/10.1016/S0168-9452(02)00415-6

Solomon, M. E. (1951). Control of humidity with potassium hydroxide, sulphuric acid or other solutions. Bulletin of Entomological Research, 42, 543-554. http://dx.doi.org/10.1017/S0007485300028947

Taiz, L., \& Eduardo, Z. (2002). Plant Physiology (3rd ed., p. 306). Sinauer Associates.

Thomas, P. M. (1984). Swathing-Combining, Storage and Conditioning of Canola (pp. 1101-1215). In Canola Growth Manual. Canola Council of Canada, Winnipeg, Manitoba.

Tys, J., \& Rybacki, R. (2001). Rapeseed: Seed quality, harvest, drying and storing processes. Acta Agrphysics Nr.44. Inst. Agrofizyki PAN.Lublin S.75.

Van Huijsduijnen, R. A. M. H., Alblas, S. W., De Rijk, R. H., \& Bol, J. F. (1986). Induction by of Pathogenesis-related Proteins and Resistance to Alfalfa Mosaic Virus Infection in Various Plant Species. Journal of General Virology, 67(10), 2135. http://dx.doi.org/10.1099/0022-1317-67-10-2135

Velasco, J., Anderson, M., \& Skibsted, L. H. (2003). Evaluation of oxidative stability of vegetative oils by monitoring the tendency to radical formation. A comparison of electron spins resonance spectroscopy with the Rancimal method and differential scanning cabrimetry. Food Chem., 77, 623-632.

Wallace, H. A. H., Sholberg, P. L., Sinha, R. N., \& Mur, W. E. (1983). Biological physical and chemical changes in stored wheat. Mycopathologia, 82, 65-72. http://dx.doi.org/10.1007/BF00437333

Zhang, S., Moyne, A. L., Reddy, M. S., \& Kloepper, J. W. (2002). The role of salicylic acid in induced systemic resistance elicited by plant growth- promoting rhizobacteria against blue mold of tobacco. Biological Control, 25, 288-296. http://dx.doi.org/10.1016/S1049-9644(02)00108-1

\section{Copyrights}

Copyright for this article is retained by the author(s), with first publication rights granted to the journal.

This is an open-access article distributed under the terms and conditions of the Creative Commons Attribution license (http://creativecommons.org/licenses/by/3.0/). 